\title{
Short Communication: New insights into the morphology and distribution of the Philippine endemic Etlingera pilosa (Zingiberaceae)
}

\author{
MARK ARCEBAL K. NAIVE ${ }^{1,2,3, \boldsymbol{v}}$, CESAR G. DEMAYO ${ }^{1}$, GRECEBIO JONATHAN D. ALEJANDRO ${ }^{4}$ \\ ${ }^{1}$ Department of Biological Sciences, College of Science and Mathematics, Mindanao State University-Iligan Institute of Technology. Andres Bonifacio \\ Ave, Iligan City, 9200 Lanao del Norte, Philippines. "email: arciinaive19@ gmail.com \\ ${ }^{2}$ Center for Integrative Conservation, Xishuangbanna Tropical Botanic Gardens, Chinese Academy of Sciences. Mengla, Yunnan 666303, China. \\ ${ }^{3}$ University of Chinese Academy of Sciences. Beijing 100049, China \\ ${ }^{4}$ Research Centre for the Natural and Applied Sciences, College of Science, and the Graduate School, University of Santo Tomas. España Boulevard, \\ 1015 Manila, Philippines
}

Manuscript received: 9 June 2021. Revision accepted: 12 July 2021.

\begin{abstract}
Naive MAK, Demayo CG, Alejandro GJD. 2021. Short Communication: New insights into the morphology and distribution of the Philippine endemic Etlingera pilosa (Zingiberaceae). Biodiversitas 22: 3175-3179. Etlingera pilosa Poulsen \& Docot, only known in Negros Oriental and Negros Occidental of Visayas islands, Philippines, is recorded in the island of Mindanao for the first time, thus, extending its distributional range. The species is characterized by having sericeous ligule; leaves subsessile, narrowly obovate, coriaceous, glabrous adaxially, densely pubescent abaxially; inflorescence up to $12 \mathrm{~cm}$ long; flowers yellow, $3.0-3.2 \mathrm{~cm}$ long; subglobose to obovoid, pilose, with wart like blunt spines fruit; and seeds irregularly subglobose to oblate, black, fully embedded in juicy sour-sweet white aril. This species closely resembles E. pubimarginata but differs in having densely pubescent abaxial leaf, sericeous ligule and subglobose to obovoid, pilose, with wart like blunt spines fruit. Here, we provide a detailed description, comparison with its allied species, colored photographs to aid identification, a distribution map, an IUCN conservation assessment and a taxonomic key to the Mindanao Etlingera species.
\end{abstract}

Keywords: Alpinieae, biodiversity, Mindanao, Philippine flora, Zingiberales

\section{INTRODUCTION}

Etlingera Giseke is a genus of the ginger family belonging to subfamily Alpinioideae, tribe Alpinieae, with about 150 species distributed from Bhutan to Fiji, most of which are occurring in equatorial Malesia (Poulsen \& Bau 2017; Poulsen \& Docot 2018). At present, Etlingera is represented in the Philippines with 17 species, 10 of which are endemic (Pelser et al. 2011; Poulsen \& Docot 2018; Naive et al. 2020). The genus is less explored in the Philippines, most specifically in the island of Mindanao, but future fieldwork would probably result in the discovery of more species either endemic or as new records from neighboring countries.

Materials of an interesting Etlingera species were collected during the first author's botanical exploration in Mount Hamiguitan Range Wildlife Sanctuary (MHRWS), Mindanao Island in September 2018. After a meticulous examination of its morphology and comparison with protologues and digitized type specimens of Etlingera species from the Philippines and neighboring countries, we found it matched with Etlingera pilosa Poulsen \& Docot. Etlingera pilosa was originally described as Amomum lepicarpum var. pubescens by Ridley (1908) based on Elmer's specimens collected from Cuernos de Negros Mountains, Dumaguete, Negros Oriental. Elmer (1919) and Merrill (1923) recognized it at species rank then transferred it to Hornstedtia and Amomum, respectively. Until now, only a 21-words long description of Etlingera pilosa was provided in the protologue with limited accompanied information.

This paper aimed to provide: (i) an extensive description of the Etlingera species rediscovered in the island of Mindanao, (ii) photographs to aid accurate identification, (iii) an updated information of its geographical distribution, and (iv) a taxonomic key leading to the Etlingera species of Mindanao Island.

\section{MATERIALS AND METHODS}

The measurement and description of the species were based on the examinations of photographic images of plants in situ, live specimens, and specimens deposited at the University of Santo Tomas Herbarium (USTH). The style of description follows the recent work of Naive et al. (2019), with general plant descriptive terminology following Beentje (2016). Since there are no species-level revisions of the whole family, all type specimens of Amomum, Etlingera and Hornstedtia spp. from the Philippines were examined in different herbaria (BM, $\mathrm{BISH}, \mathrm{BO}, \mathrm{E}, \mathrm{F}, \mathrm{G}, \mathrm{HBG}, \mathrm{K}, \mathrm{L}, \mathrm{MO}, \mathrm{NY}$, and US) through high-resolution images accessed at https://plants.jstor.org/. Informal conservation status category was assessed by range size (B criterion), following IUCN Standards and Petitions Subcommittee (2019) recommendations. The 
extent of occurrence (EOO) and area of occupancy (AOO) were estimated using Geospatial Conservation Assessment Tool (GeoCAT) (Bachman et al. 2011).

\section{RESULTS AND DISCUSSION}

A comprehensive taxonomic treatment, basionym, synonym, distribution and habitat, phenology, specimens examined, conservation status, photographs and notes of this newly recorded species are provided below.

Etlingera pilosa A.D. Poulsen \& Docot, Edinburgh J. Bot. 76(1): 40 (2018); Amomum lepicarpum var. pubescens Ridl., Leafl. Philipp. Bot. 2: 605. (1909); Hornstedtia pubescens (Ridl.) Elmer, Leafl. Philipp. Bot. 8: 2979. (1919); Amomum pubescens (Ridl.) Merr., Enum. Philipp. Fl. Pl. 1: 240. (1923). (Figs. 1-2).

Type: Philippines, Visayas, Negros Island, Negros Oriental, Dumaguete, Cuernos de Negros Mts, $3500 \mathrm{ft}$, vi 1908, A.D.E. Elmer 10284 (lecto: K00255023, first step effectively designated by Turner (2000), second step effectively designated by Poulsen \& Docot (2018); isolecto: BISH, BM, BO, E, G, HBG, K, L, NY, US, Z).

Description: Terrestrial herb. Rhizome $1.5-2 \mathrm{~cm}$ in diameter, brownish, glabrous, covered with persistent scales, roots $4-5 \mathrm{~mm}$ in diameter, scales $3-4.5 \times 2-3.6 \mathrm{~cm}$, boat-shaped to broadly ovate, caducous, coriaceous, striate, base pubescent, reddish-brown to reddish maroon; stilt roots absent. Leafy shoot up to $2.5 \mathrm{~m}$ long, arching, composed of up to 25 leaves, $8-12 \mathrm{~cm}$ between neighboring leafy shoots, basal $1 / 3$ leafless; base swollen, 3-4 cm in diameter, reddish-brown; sheath green, less ribbed, pubescent, margin membranous, reddish; ligule 8 $10 \times 5-7 \mathrm{~mm}$, entire, ovate, sericeous, green to brownish green, margin ciliated, apex obtuse; petiole subsessile, 5-8 $\mathrm{mm}$ long, green, glabrous; lamina $40-45 \times 11-13 \mathrm{~cm}$, narrowly obovate, coriaceous, green, pale beneath, adaxially glabrous, abaxially densely pubescent, margin reddish, ciliated, base cuneate, apex acuminate, midrib adaxially canaliculate, glabrous, abaxially protruding, pubescent. Inflorescence up to $12 \mathrm{~cm}$ long; sterile bracts $3-$ $3.5 \times 1.3-1.5 \mathrm{~cm}$, boat-shaped to ovate, coriaceous, striate, deep purple-red to reddish-brown, pubescent, margin slightly membranous, apex mucronate, acute; fertile bracts $2.2-2.5 \times 1.3-1.7 \mathrm{~cm}$, narrowly obovate to boat-shaped, canaliculate, maroon to dark red, glabrous except the center of the base, apex mucronate; bracteoles 2-2.2 cm long, coriaceous, with two fissures of 4-5 mm long, glabrous except the sparsely puberulous basal $1 / 3$, apex 2-dentate, unequal. Flowers 3.0-3.2 cm long; calyx $2.3-2.5 \mathrm{~cm}$ long, reddish, paler at base, sericeous, apex trilobed, lobes 3-4 $\mathrm{mm}$ long, subacuminate; staminal tube $1-1.5 \mathrm{~cm}$ long, yellowish red to pale red, sparsely sericeous; corolla lobes oblong to oblanceolate, cucullate, red to pale red, glabrous both sides, reaching $1 \mathrm{~mm}$ beyond apex of the anther, apex obtuse to rounded; dorsal corolla lobe 13-15 $\times 5-6 \mathrm{~mm}$; lateral corolla lobes $13-15 \times 3-4 \mathrm{~mm}$, slightly falcate; labellum 10-12 × 5-6 mm, erect, fleshy, yellow, pale yellow at base, ventrally tomentose at the center, margin entire, lateral lobes embracing the anther, central lobe extending up to $5 \mathrm{~mm}$ long, apex obtuse to rounded; stamen 7-9 $\mathrm{mm}$ long; filament $3-5 \mathrm{~mm}$ long, cream, hyaline; anther $4-4.5 \mathrm{~mm}$ long by $2 \mathrm{~mm}$ in diameter, parallel side, sericeous, pale yellow to creamy white, anther crest emarginate (up to 1-1.2 mm), thecae dehiscent, sericeous; ovary 5-6.5 $\mathrm{mm}$ long by 3-4 $\mathrm{mm}$ wide, brown to reddish-brown, sericeous, barrel-shaped; style $2.5-2.8 \mathrm{~cm}$ long, creamy white, sparsely sericeous; stigma 1-2 mm wide, tomentose, ostiole 1-1.2 mm, oblong, facing forward to upwards; epigynous gland 3-3.5 mm long, entire, split to apex dorsally, apices blunt, with tufted trichomes. Fruit $1.5-1.8 \times 1.3-2 \mathrm{~cm}$, subglobose-obovoid, pilose, rufous or reddish-brown, covered with persistent bracts, bearing the calyx, apex truncate, with wart-like, blunt spines; seeds 2-4 $\mathrm{mm}$ in diameter, irregularly subglobose to oblate, black, fully embedded in juicy sour-sweet white aril.

Habitat and distribution: Found in primary to secondary broad-leaved dipterocarp forests with open to semi-open canopy and humid environment usually near a river or stream (c. 20-50 m away from the river or stream) at elevations between 300-500 m asl. Etlingera pilosa has so far only been known from its type locality which is in Cuernos de Negros, Negros Oriental and Mt. Kanalon, Negros Occidental of Visayas (Pelser et al. 2011). However, recent botanical exploration in the island of Mindanao revealed that it is also present in Mt. Hamiguitan Range Wildlife Sanctuary (MHRWS), Davao Oriental. In September and November 2018, the species has also been documented in the province of Surigao del Norte and Surigao del Sur, Philippines (Rule, pers. comm.). Therefore, extending its distributional range and a new species record for the island of Mindanao (Fig. 3).

Phenology: Observed flowering and fruiting in the field in April and September to December.

Specimen examined: PHILIPPINES: Visayas, Negros Oriental, Dumaguete, Cuernos Mountains, $1100 \mathrm{~m}$, June 1908, A.D.E. Elmer 10384 (K-image seen!); Mindanao, Davao Oriental, San Isidro, La Union, Mount Hamiguitan Range Wildlife Sanctuary, elev. $431 \mathrm{~m}, 21$ September 2018, M.A.K. Naive 107 (USTH, new provincial record).

Conservation status: There are five localities known for this species, including its historic type locality giving an Extent of Occurrence (EOO) of 70,570.208 $\mathrm{km}^{2}$ when calculated using GeoCAT system (Bachman et al. 2011). Each has a healthy population and observed also to thrive in disturbed areas. Following the Red List criteria of the IUCN Standards and Petitions Subcommittee (2019), the species is herein provisionally treated as Least Concern (LC). The assessment shall be updated as more information becomes available.

Taxonomic affinities. By having a short, yellow labellum, E. pilosa is closely similar to E. pubimarginata (Elmer) A.D.Poulsen. However, the former differs significantly by having the following characters: densely pubescent abaxial leaf (vs. glabrous both sides in E. pubimarginata), sericeous ligule (vs. glabrous in E. pubimarginata), and subglobose-obovoid, rufous or red, pilose, with wart-like, blunt spines on fruit (vs. subglobose-ovoid, reddish-brown to red orange, densely covered with shining yellowish trichomes fruit in E. pubimarginata). 


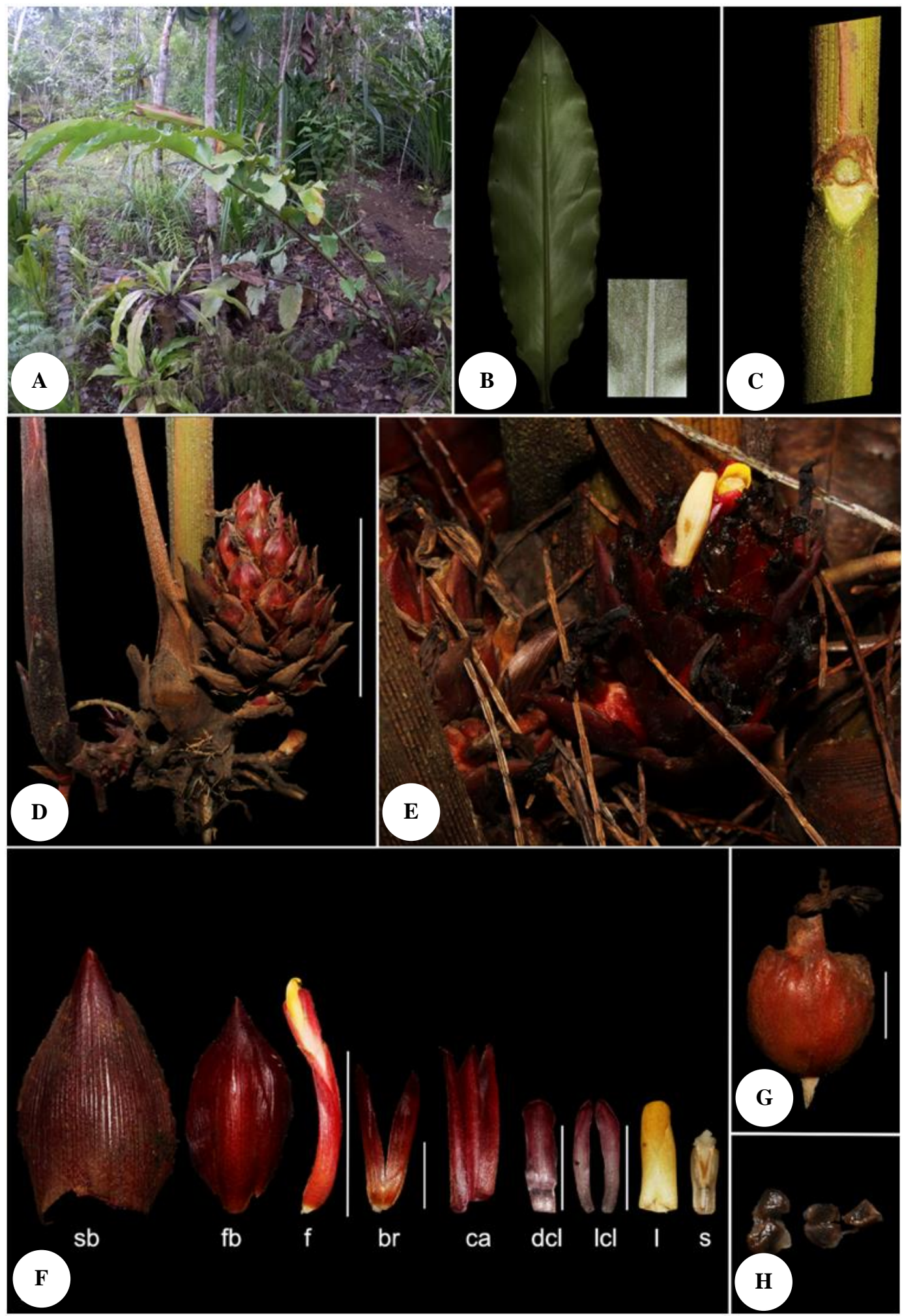

Figure 1. Etlingera pilosa Poulsen \& Docot: A. Habit; B. Leaf, detail of abaxial leaf; C. Detail of ligule; D. infructescence excavated (scale bar $10 \mathrm{~cm}$ ); E. inflorescence; F. floral dissection (sb, sterile bract; fb, fertile bract; f, flower (scale bar $2 \mathrm{~cm}$ ); br, bracteole (scale bar $1 \mathrm{~cm}$ ); c, calyx; dcl, dorsal corolla lobe (scale bar $1 \mathrm{~cm}$ ); lcl, lateral corolla lobes (scale bar $1 \mathrm{~cm}$ ); 1, labellum; s, stamen); G. Fruit (scale bar $1 \mathrm{~cm}$ ); H. Seeds. Photos by MAK Naïve 


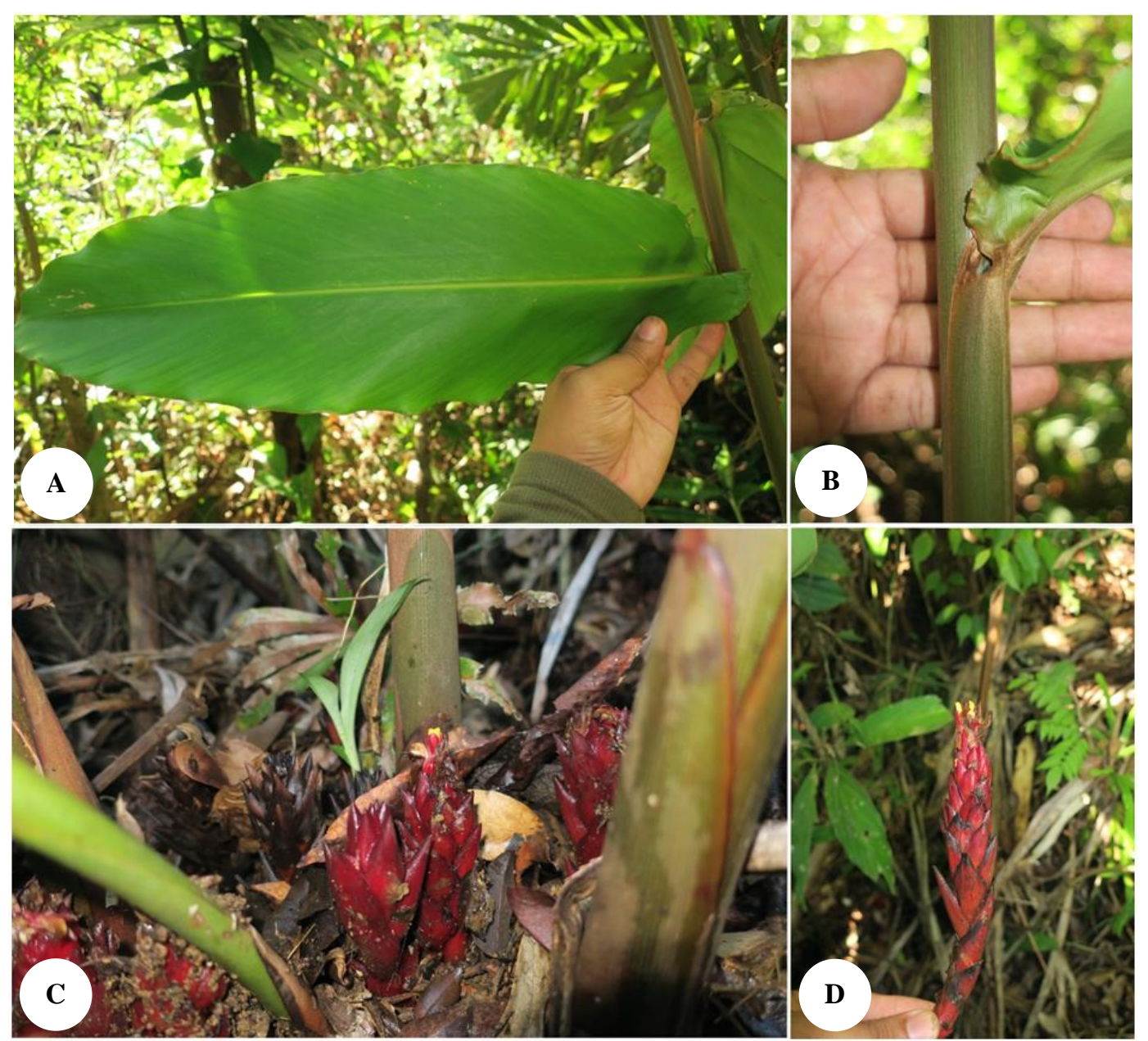

Figure 2. Etlingera pilosa documented in Surigao del Norte: A. Leaf; B. Detail of ligule; C-D. Inflorescences. Photos by Mark G. Rule

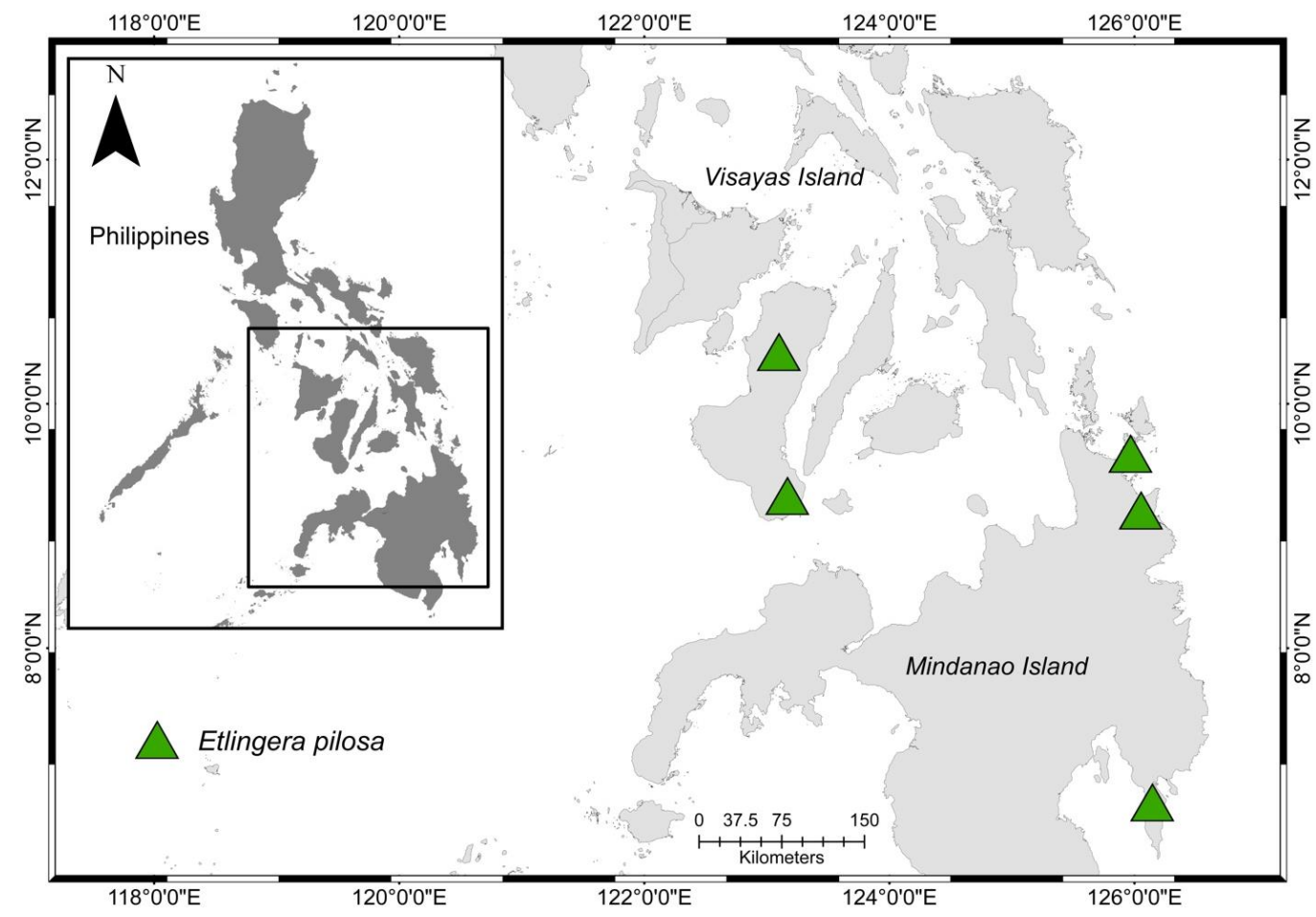

Figure 3. Map showing the distribution of Etlingera pilosa 


\section{Key to the Mindanao Etlingera species}

1. Central lobe of the labellum short, $<2 \mathrm{~cm}$ long .2

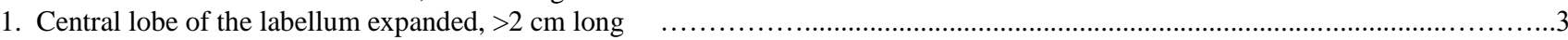

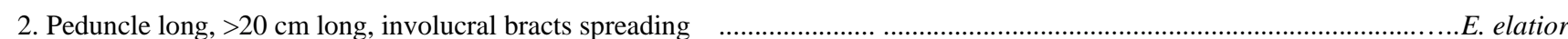

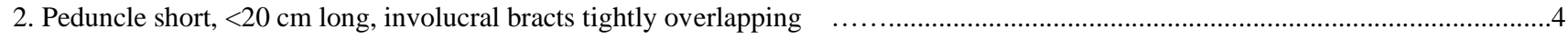

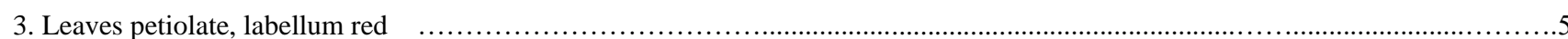

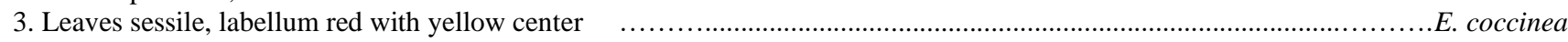

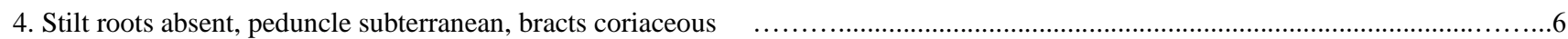

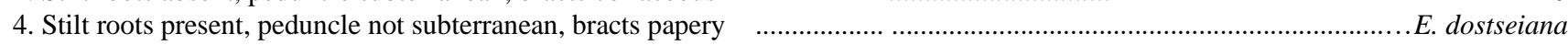

5. Leaves pubescent abaxially, central lobe of the labellum bilobed $\quad$......................................................................... E. hamiguitanensis

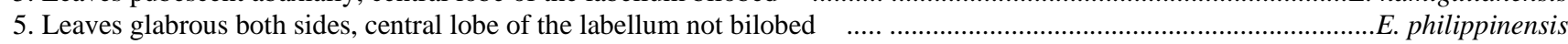

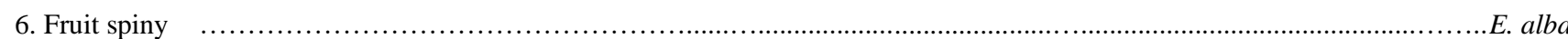

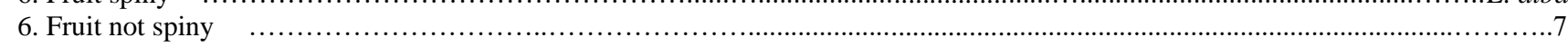

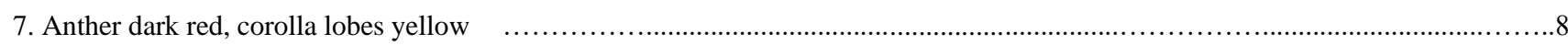

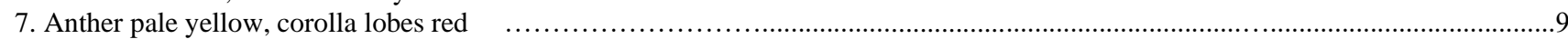

8. Anther crest present, stamen yellow $\quad$............................................................................................. fimbriobracteata

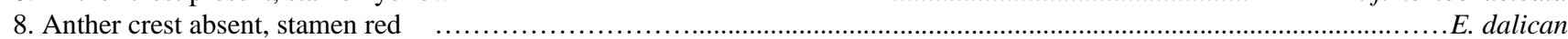

9. Abaxial leaf pubescent, fruit pilose, with wart-like, blunt spines $\quad$................................................................................. pilosa

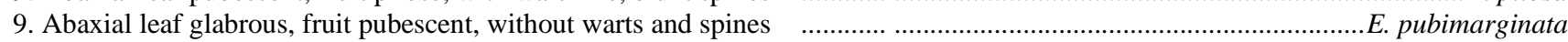

\section{ACKNOWLEDGEMENTS}

The first author would like to acknowledge Tatay Pidoy and Dr. Nickel Lagare for accompanying him during the fieldwork in Mount Hamiguitan Range Wildlife Sanctuary; DENR Region XI for the Gratuitous Permit (No. XI-201903) issuance; Clint Michael B. Cleofe for his assistance in Gratuitous Permit application for MHRWS; Mark Gregory Rule for giving us information about the species in Surigao del Norte and Surigao del Sur as well as for allowing us to use his photos; Kean Roe F. Manzo for producing the distribution map; and Department of Science and Technology - Science Education Institute (DOST-SEI ) for the research grant.

\section{REFERENCES}

Bachman S, Moat J, Hill A, De La Torre J, Scott B. 2011. Supporting Red List threat assessments with GeoCAT: Geospatial Conservation Assessment Tool. ZooKeys 150: 117-126. DOI: 10.3897/zookeys.150.2109.

Beentje H. 2016. The Kew Plant Glossary, an Illustrated Dictionary of Plant Terms, 2nd ed. Royal Botanic Gardens (Kew), Kew Publishing, Kew.
Elmer ADE. 1915. Notes and description of Zingiberaceae. Leaflets of Philippine Botany 8: 2885-2919.

Elmer ADE. 1919. Zingiberaceae of the Sorsogon Peninsula. Leaflets of Philippine Botany 8: 2963-2995.

IUCN Standards and Petitions Subcommittee. 2019. Guidelines for Using the IUCN Red List Categories and Criteria. Version 13. Prepared by the Standards and Petitions Subcommittee. http://www.iucnredlist.org/

JSTOR. 2021. Global Plants. http://plants.jstor.org/.

Leong-Škorničková J, Newman MF. 2015. Gingers of Cambodia, Laos and Vietnam. Botanic Gardens Edinburgh and Pha Tad Ke Botanical Gardens, Luang Prabang, Laos.

Merrill ED. 1923. An Enumeration of Philippine Flowering Plants. Bureau of Science, Manila.

Naive MAK, Demayo CG, Alejandro GJD. 2019. Rediscovery and new data on distribution of the imperfectly known Philippine endemic species Etlingera pubimarginata (Zingiberaceae; Alpinieae). Phytotaxa 394 (1): 105-110. DOI:10.11646/phytotaxa.394.1.8

Naive MAK, Demayo CG, Alejandro GJD. 2020. Etlingera dostseiana (Zingiberaceae), a new species from Mindanao, Philippines. Annales Botanici Fennici 58: 33-36. DOI: 10.5735/085.058.0106.

Pelser PB, Barcelona JF, Nickrent DL. 2011. Co's Digital Flora of the Philippines.

Poulsen AD, Bau BB. 2017. A new species of Etlingera (Zingiberaceae) from Bougainville Island, Papua New Guinea. Edinburgh J Bot 74: 141-148. DOI: 10.1017/S0960428617000026.

Poulsen AD, Docot RVA. 2018. How many species of Etlingera (Zingiberaceae) are there in the Philippines? Edinburgh J Bot 76: 3344. DOI: $10.1017 /$ S0960428618000240.

Ridley HN. 1909. Zingiberaceae from south Negros. Leaflets of Philippine Botany 7: 603-607. 